\title{
Economic Determinants of Corporate Capital Structure: The Case of Tunisian Firms
}

\author{
Abderrazek Elkhaldi ${ }^{1}$ \& Wissem Daadaa ${ }^{2}$ \\ ${ }^{1}$ Faculty of Economics and Management-Sousse Tunisia, University of Sousse, Tunisia \\ ${ }^{2}$ Faculty of Economics and Management-Nabeul Tunisia, Carthage University, Tunisia \\ Correspondence: Abderrazek Hassen Elkhaldi, Faculty of Economics and Management, University of Sousse, \\ Tunisia. E-mail: abderrazek.elkhaldi@yahoo.fr
}

Received: June 9, 2015

Accepted: June 26, 2015

Online Published: August 25, 2015

doi:10.5539/ijef.v7n9p193

URL: http://dx.doi.org/10.5539/ijef.v7n9p193

\begin{abstract}
This study examines the impact of stock trading on capital structure using a sample of Tunisian publicly traded firms over the period 2002-2012. The study uses General least square regressions. Our results show that macroeconomic variables related to monetary policy and Fiscal policy have an impact on leverage. This relationship is positive for the case of Interest Rate (INT) and Unemployment Rate (UR) and negative for the case of Inflation Rate (IR). Moreover, we found that this relationship is robust for short term book leverage. However, for the long term, we found that only Interest Rate and Unemployment Rate have strong positive impact on leverage.
\end{abstract}

Originality/value-This is the first paper that examines the relationship between Macroeconomics determinants and capital structure in Tunisia.

Keywords: capital structure, debt, leverage, fiscal policy, monetary policy

\section{Introduction}

Despite its importance in explaining stock price mechanism, the cost of capital theory has not sufficiently progressed. In fact, we are still hostages of two main approaches of Pecking Order Theory and Trade Off theory, both related to the traditional financial theory that has been eroded by Modigliani and Miller (1958). Since, several studies have been carried out by introducing different parameters such as tax, bankruptcy cost, agency costs... The main results of those studies led to define an optimal capital structure that combines different funding methods (own funding, liability...).

However, this approach remains elitist, theoretical and far from the financial reality. Moreover, the implications of this theory are different, since we consider the long-term horizon or the short-term one even if investors prefer the latter.

The aim of each firm is to reduce its capital cost. This requires an optimal combination of funding sources especially debt and equity. Such combination depends on many microeconomic and macroeconomic factors. The literature studying the first category is very developed, but the macroeconomic approach is still scanty and little used.

The aim of this paper is to study the impact of macroeconomic factors on firm's capital cost in the case of Tunisian companies.

Consequently, the paper will be organized as follows: Section two provides a literature review studying the impact of macroeconomic factors on firm's capital cost for different contexts, especially for the case of merging and developing countries. Section three presents the model and the data. Section four will expose and discuss the main results and finally section five will conclude.

\section{Literature Review}

\subsection{Theoretical Background}

The impact of monetary policy on firm's financial decision is no longer contesting, simply because managers have become connected to the decisions taken by monetary authorities in order to build their own strategies and 
their financial decisions. In fact, the last decade has been characterized by a new tendency in monetary policy henceforth based on fighting inflationary pressure and managing production rather than combating poor fiscal policy (Mishkin, 1996). This could be explained to our senses by the tax record reached by a large majority of countries (ex: in, France it represents about $45 \%$ of an individual income, see http://www.impots.gouv.fr/portal/dgi/public/popup?espId=0\&typePage=cpr02\&docOid=documentstandard_6117 ).

Hence, the aim of both economists and politicians is to stabilize prices and to fight inflation. The classical assumption provided by Keynes (1937) is always valid for nowadays. In fact, an expansionist monetary policy could be reached by a decrease in real interest rate. Such decrease reduces cost of capital, encourages investments and stimulates production. In this sense, Taylor (1995) considers that interest rate exerts a significant effect on investment and capital cost. However, Bernanke and Gertler (1993) maintain that this significant effect was not empirically proved and propose to focus on other mechanisms such as exchange rate and financial assets. Moreover, Bryant, Hooper and Mann (1993) consider that monetary policy based on interest rate is counterproductive and that we should manage inflation through exchange rate control and financial stock market dynamics.

In the case of exchange rate, it is believed that its fluctuation affects significantly a firm choice towards financing. Allayannis et al. (2002) maintain that local currency depreciation may lead firms to decrease their foreign debts, which may cause an increase in capital cost especially when foreign financing cost is lower. This result was confirmed by several studies such as Bryant et al. (1993), Taylor (1993) and more recently by Broll and Wong (2006).

Concerning the impact of financial stock market on capital cost, we distinguish two basic mechanisms; the Tobin's q and the welfare effect of Modigliani (1971).

The first mechanism was introduced by Tobin (1969) which represents the ratio between a physical asset's market value and its replacement value. A high value of Tobin's q is equivalent to a high market value compared to the capital replacement cost. In other words, the cost of capital for all new productive investments will obviously decrease and vice versa.

The second mechanism provided by Modigliani (1971) is related to life cycle effect. According to Modigliani (1971), a consumer spending is closely related to his resource level throughout his life (human capital, material capital and financial capital). As a consequence, any increase of one of his resources will certainly affect his consumption behavior. In this case, an increase in individual stock price valuation will raise his wealth level and then his consumption, which leads to an increase in both investment and production.

\subsection{Review of Empirical Studies}

Abzari et al (2012) examine the effect of macroeconomic variables as perceived by financial manager on firm's capital structure decision. Using a sample of 100 listed firms in Tehran Stock Exchange, they didn't find any significant relationship between perceived macroeconomic variables and Iranian capital structures. However, the administrated questionnaire lead authors to deduce that Iranian managers express a significant effect of some macroeconomic variables such as inflation rate, exchange rate and interest rate.

Riaz et al. (2014) used an economic factors model in order to check the effect of macroeconomic factors on firm's capital structure in the case of Pakistani firms. They found that GDP growth rate has a significant negative impact on debt ratio which means that Pakistani firms tend to choose own funding to debt when GDP growth rate increases.

Baum et al. (2014) showed that macroeconomic risk affects significantly firm's capital structure especially for firms with high specific risk.

Pindado et al. (2014) studied the impact of monetary policy on corporate debt decisions using a panel of 16,743 listed companies covering 33 countries during the period 2004-2011. They found that monetary policy facilitates firm's access to debt regardless of their specific financial constraints and borrowers' information. Moreover, they found that constrained firms are more sensitive to macroeconomic conditions.

In the case of European countries, Mokhova and Zinecker (2014) have studied the impact of macroeconomic factors on corporate capital structure. Considering a sample of 7 European countries during the period 2006-2011, they found that managers of emerging countries of the sample often build their financing strategies according to macroeconomic context and that impact of considered macroeconomic factors on capital cost depends on corporate debt structure and countries fundamentals. 
Muthama et al. (2013) have analyzed the impact of macroeconomic factors on capital structure in the context of Kenya. Using a multiple linear regression model, they found a positive influence of GDP growth, a negative influence of debt ratio and of inflation and a positive impact of interest rate as measured by the treasury bills.

Mahmud et al. (2009) attempted to determine the factors that influence a firm's capital structure in three Asian countries: Japan, Malaysia and Pakistan. Their results have shown that higher economic growth tends to encourage using more long term debt.

\section{Model and Data}

Our sample includes all Tunisian firms listed on the Tunis Stock Exchange (TSE) for the period 2002-2013. We exclude financial firms because of their different capital structure. We obtain a final sample of 30 non-financial firms. The financial and accounting data are manually collected from annual reports and the TSE statistics.

To calculate dependant variable, we use two alternative measures of leverage, short term book leverage (STBL) and long-term book leverage (LTBL).

Short term book leverage is defined as book value of short term debt divided by book value of assets. Long-term book leverage represented by long-term liabilities to total assets and short-term book leverage represented by short-term liabilities to total assets, in order to take into consideration structure of debt.

The macroeconomic factors used to explain the corporate capital structure are related to monetary and fiscal policies. Other variable such as Gross Domestic Product growth rate (GR) will be used to capture economic development and stability level.

The variables of monetary policy are: inflation rate (IR) and money policy (M) as percentage of gross domestic product GDP, which indicate monetary conditions in general. Interest rate variable even fixed by the central bank is a key variable in our study. It provides information about development level of financial stock market and banking.

Fiscal policy is measured by variables as central government debt to GDP (GD), tax revenue as percentage of GDP (TR), income taxes as percentage of revenue (IT).

The variables unemployment rate (UR) and Gross Domestic Product growth rate (GR), feature macroeconomic development and economic stability.

To study the link between external determinants and capital structure, we use the following model:

$$
\text { Leverage }_{i, t}=\propto_{0}+\propto_{1} I R+\propto_{2} M+\propto_{3} G D+\propto_{4} I N T+\propto_{5} T R+\propto_{6} I T+\propto_{7} U R+\propto_{8} G R+\varepsilon
$$

Table 1. Dependant variable: STBL

\begin{tabular}{ccccc}
\hline Variable & Coefficient & Std. Error & t-Statistic & Prob. \\
\hline C & -13.03300 & 20.68963 & -0.629929 & 0.5293 \\
IR & $\mathbf{- 0 . 1 3 3 4 7 1 * *}$ & $\mathbf{0 . 0 5 9 4 8 7}$ & $\mathbf{- 2 . 2 4 3 6 9 2}$ & $\mathbf{0 . 0 2 5 8}$ \\
M & 1.515599 & 2.843593 & 0.532987 & 0.5945 \\
INT & $\mathbf{0 . 3 7 1 9 0 9 * * *}$ & $\mathbf{0 . 1 4 1 9 2 1}$ & $\mathbf{2 . 6 2 0 5 2 8}$ & $\mathbf{0 . 0 0 9 3}$ \\
GD & -0.278031 & 0.733033 & -0.379288 & 0.7048 \\
TR & 1.377667 & 2.072508 & 0.664734 & 0.5069 \\
IT & -0.998689 & 1.570171 & -0.636038 & 0.5254 \\
UR & $\mathbf{1 . 1 0 9 9 4 4 * *}$ & $\mathbf{0 . 4 9 8 5 2 3}$ & $\mathbf{2 . 2 2 6 4 6 4}$ & $\mathbf{0 . 0 2 6 9}$ \\
GR & 0.099639 & 0.083598 & 1.191881 & 0.2345 \\
\hline
\end{tabular}

R-squared 0,46

Note. * Significant at the $10 \%$ level, ** significant at the $5 \%$ level and $* * *$ significant at the $1 \%$ level.

Table 1 Effect of external variables on short term leverage: This table provides the regression results of macroeconomic variables on capital structure using two measures of leverage (short term book leverage and long term book leverage). 
Table 2. Dependant variable: LTBL

\begin{tabular}{ccccc}
\hline Variable & Coefficient & Std. Error & t-Statistic & Prob. \\
\hline C & -9.891099 & 7.701969 & -1.284230 & 0.2003 \\
IR & -0.001525 & 0.024051 & -0.063403 & 0.9495 \\
M & 1.421004 & 1.047937 & 1.356001 & 0.1764 \\
INT & $\mathbf{0 . 1 0 4 0 1 4 * *}$ & $\mathbf{0 . 0 4 8 4 8 6}$ & $\mathbf{2 . 1 4 5 2 2 4}$ & $\mathbf{0 . 0 3 2 9}$ \\
GD & 0.028095 & 0.265272 & 0.105909 & 0.9157 \\
TR & 0.701849 & 0.817234 & 0.858810 & 0.3913 \\
IT & -0.739086 & 0.601013 & -1.229735 & 0.2200 \\
UR & $\mathbf{0 . 4 8 4 8 4 8 * *}$ & $\mathbf{0 . 2 0 7 1 5 9}$ & $\mathbf{2 . 3 4 0 4 6 6}$ & $\mathbf{0 . 0 2 0 1}$ \\
GR & 0.046289 & 0.032713 & 1.415004 & 0.1584 \\
R-squared 0,36 & & & & \\
\hline
\end{tabular}

Note. * Significant at the $10 \%$ level, ** significant at the $5 \%$ level and *** significant at the $1 \%$ level.

Table 2 Effect of external variables on Long term leverage: This table provides the regression results of macroeconomic variables on capital structure using two measures of leverage (short term book leverage and long term book leverage).

\section{Results and Discussion}

Tables 1 and 2 present the regression results for the capital structure equation using the two alternative measures of leverage: short term book leverage and Long term book leverage.

Our results show that macroeconomic variables related to monetary policy and Fiscal policy have an impact on leverage.

This relationship is positive between interest rate and leverage and negative between inflation rate and leverage. Moreover, it is positive with Unemployment Rate.

This relationship is robust for short term book leverage but on long term, only interest rate and Unemployment Rate have strong positive impact on leverage.

The economic implications of those results are the following:

Inflation rate (IR) is negatively related to book leverage. This result corroborates Bhamara, Fisher, and Kuehn (2011) that argue that monetary policy influences corporate capital structure and essentially inflation rate. Though, Abaidoo and Kwenin (2013) conclude that leverage is positively influenced by inflation rate proving the leveraged impact of inflation (see Campbell, 1988; and Barr \& Campbell, 1996). In the case of Tunisia, the negative relationship can be explained by recession effect and investors sentiments. Two explanations that can be supported by the interest rate result analysis. In fact, central bank determines the country monetary policy, ensures the balance between supply and demand of money and adjusts the interest rate to reach equilibrium. To encourage investment and then to reduce the unemployment rate, central bank decreased interest rate (after revolution year in 2010); such measure has encouraged consumption and consequently increased the price and therefore the inflation rate.

To decrease the inflation rate, the major policy instrument used by the central bank of Tunisia is the interest rate. This means that, central bank can fix target inflation rate and then changes interest rate to preserves this target.

The Central bank of Tunisia has found some difficulties to achieve this target using only the interest rate instrument. With the decline in bank liquidity, the central bank was forced to increases supply liquidity on the monetary market. The expansionist policy by central bank has caused the prices growth and therefore increased the inflation rate. As a consequence, the security prices have been affected, and the stock return and the capital cost have significantly increased, threatening some projects to the extent that they became unprofitable. Consequently, this relationship affects the economic growth rate and even securities market prices. In such context, firms are going to prefer debt rather than own financing, then leverage will increase.

The increase of capital cost causes the unprofitability of some investments and then has a positive effect on leverage. This result is consistent with the pecking order theory, suggesting that firms use retained earnings first to finance investment, and therefore more profitable firms will be less leveraged. This finding corroborates the results of Daadaa and Khediri (2011).

For the second control variables related to fiscal policy and stability, we find results consistent with prior studies. 
Unemployment rate has a positive and significant effect on both short and long term leverage.

To stabilize the economy, government adjusts its fiscal policy and public expenditure in short and in long term. The short-term goal is to increase economic growth and improve the citizens living. The long term goal is to reduce unemployment rate and inflation rate.

The augment in government public spending, especially after 2010, generates a massive increase in consumer spending and corporate sales. The raise in personnel wage and the decline of the production caused the bankruptcy of several companies and then raised unemployment rate. This inexistence of internal resources forces company to seek debt and then increases leverage.

\section{Conclusion}

The uncertainty and the political instability caused by the social crisis of December, 17th 2010, have placed the Tunisian economy at multiple difficulties. In fact, they caused the discouragement of both domestic and foreign investments and a depression in tax revenue and foreign exchange reserves.

in such a situation, the only instrument that central bank could manipulate was interest rate in order to stabilize prices, promote non inflationary growth and improve welfare. thus, a first decision of reducing the interest rate was made so as to encourage new investments. however, it had no positive effect. so, the central bank decided to act otherwise by increasing the interest rate and rationing consumer credits. This has lead to an exorbitant increase of inflation rate, unemployment rate and a collapse in investment volume. Consequently, both short term and long term leverage have been significantly affected by the rise of interest rate, leading firms to reduce their investments and then to be deprived from the subsequent financial leverage of lending.

It is commonly accepted that monetary policy is the most difficult task of a monetary authority. But for the case of Tunisia, it is more and more difficult because the political, social and economic contexts are extremely unfavorable to achieve the aims of a monetary policy. Moreover, the financial market is no sufficiently developed to provide an alternative solution for firm's financing (see Elkhaldi \& Abdelfatteh, 2014; Bellalah et al., 2006; Elkhaldi et al., 2014 ...). Another explanation for the confusing dynamics of capital cost in Tunisia is attributed to the familial aspect of Tunisian firms that leads shareholders to prefer debt to capital increase even in the case of listed companies. In fact, both managers and shareholders opt for external resources in order to get financial leverage. They seldom choose other alternatives such as financial market, especially when occasional incentives are provided by financial authorities.

Finally, it should be noted that the Tunisian managers usually build their financial decisions on the basis of monetary authority policy, especially in terms of fiscal and social incentives. Moreover, Tunisian economy suffers from a recession period conjugated with inflationary pressure. such a context, leads managers to prefer debt to capital increase and induces an artificial undesired leverage called recession effect.

We recommend to the central bank of Tunisia to improve its communication policy and to build it around the concept of "social capital" as called by the world bank and especially by Putnam "Strong society, strong state; strong society, strong economy", in order to inform both public and investors about the adopted policy and its aims. Moreover, a hard effort must be undertaken to fight inflation and to reinforce exportation and to raise foreign currency reserves. Then, a real palpable growth could be reached and observed by both domestic and foreign investors.

\section{Acknowledgments}

We would like to thank Kamel Naoui and Mohammed Imen Gallali and all the team of RIM-RAF research unit for helpful comments. Financial support from the University of Sousse and the Faculty of Economics and Management of Sousse is gratefully acknowledged.

\section{References}

Abaidoo, R., \& Kwenin, D. O. (2013). Corporate profit growth, macroeconomic expectations and fiscal policy volatility. International Journal of Economics and Finance, 5(8), 25-38. http://dx.doi.org/10.5539/ijef.v5n8p25

Abzari, M., Fathi, S., \& Nematizadeh, F. (2012). Analyzing the Impact of Financial Managers' Perception of Macroeconomic Variables on Capital Structure of Firms Listed in Tehran Stock Exchange. International Journal of Academic Research In Economics and Management Sciences, 1(3), 131-141.

Allayannis, G., Brown, G. W., \& Klapper, L. F. (2003). Capital Structure and Financial Risk: Evidence From Foreign Debt Use in East Asia. The Journal of Finance, LVIII(6). http://dx.doi.org/10.1046/j.1540-6261.2003.00619.x 
Barr, D. G., \& Campbell, J. Y. (1996). Inflation, Real Interest Rates, and the Bond Market: A Study of UK Nominal and Index-Linked Governmen Bond Prices. NBER Working Papers 5821, National Bureau of Economic Research.

Bauma, C. F., Caglayanc, M., \& Rashid, A. (2014). Capital Structure Adjustments: Do Macroeconomic and Business Risks Matter? Working Paper at the EFMA, ROME conference.

Bellalah, M., Elkhaldi, A., \& Naoui, K. (2006). The financial Deregulation in Tunisia The Impact on Market Efficiency. Euromediterranean Economic and Finance Review, 1(3), 2006.

Bernanke, B. S., \& Gertler, M. (1993). Inside The Black Box: The Credit Channel Of Monetary Policy Transmission. Journal of Economic Perspectives, 9(4), 27-48. http://dx.doi.org/10.1257/jep.9.4.27

Bhamra, S. H., Fisher, A. J., \& Kuehn, L. A. (2011). Monetary Policy And Corporate Default. Journal of Monetary Economics, 58(5), 480-494. http://dx.doi.org/10.1016/j.jmoneco.2011.05.010

Broll, U., \& Wong, K. P. (2006). Multinationals, Hedging, and Capital Structure Under Exchange Rate Uncertainty. Open Economies Review, 17, 103-114. http://dx.doi.org/10.1007/s11079-006-4744-x

Bryant, Hooper, \& Mann. (1993). Valuating Policy Regimes: New Research In Empirical Macroeconomics. Washington: The Brookings Institution.

Campbell, J. Y., \& Ammer, J. (1993). What Moves the Stock and Bond Markets? Variance Decomposition for Long-Term Asset Returns. Journal of Finance, 48(1), 3-37.

Elkhaldi, A., \& Benabdelfatteh, Y. (2014). Testing Herding Effects on Financial Assets Pricing: The Case of the Tunisian Stock Market. British Journal of Economics, Management \& Trade, 4(7), 1046-1059. http://dx.doi.org/10.9734/BJEMT/2014/8973

Elkhaldi, A., Chebbi, T., \& Naoui, K. (2014). Measuring Contagious Effects on Euro Area Debt Crisis Using Daily CDS Spreads Changes. Procedia Economics and Finance, 13, 14-29. http://dx.doi.org/10.1016/S2212-5671(14)00427-4

Keynes, J. M. (1937). The Ex Ante Theory of the Rate of Interest. Economic Journal, 47, 663-668. http://dx.doi.org/10.2307/2225323

Khediri, K., \& Daadaa, W. (2011). Stock Trading And Capital Structure in Tunisian Stock Exchange. Journal of Business Studies, 2(2011), 10-24.

Mahmud, M., Herani, G. M., Rajar, A. W., \& Farooqi, W. (2009). Economic Factors Influencing Corporate Capital Structure in Three Asian Countries: Evidence from Japan, Malaysia and Pakistan. Indus Journal of Management \& Social Sciences, 3(1), 9-17.

Mishkin, F. (1996). The Channels of Monetary Transmission: Lessons for Monetary Policy. NBER Working Paper 5464.

Modigliani, F. (1971). Consumer Spending And Monetary Policy: The Linkages. Federal Reserve Bank of Boston Conference Series, 5.

Modigliani, F., \& Miller, M. H. (1958). The cost of capital, corporate finance and the theory of investment. American Economic Review, 48, 261-297.

Modigliani, F., \& Miller, M. H. (1963). Corporate Income Taxes and the Cost of Capital: A Correction. American Economic Review, 53, 433-443.

Mokhova, N., \& Zinecker, M. (2014). Macroeconomic Factors and Corporate Capital Structure. Journal Procedia-Social and Behavioral Sciences, 110, 530-540. http://dx.doi.org/10.1016/j.sbspro.2013.12.897

Muthama, C., \& Mbaluka, K. (2013). An Empirical Analysis of Macro-Economic Influence on Corporate Capital Structure of Listed Companies in Kenya. Journal of Finance and Invesment Analysis, 2(2), 41-62.

Pindadoa, J., Requejoa, I., \& Rivera, J. C. (2014). Which Macroeconomic Factors Facilitate Corporate Financing? EFMA Annual Meetings, Rome 2014.

Putnam R. (1993). The prosperous community. Social capital and public life. The American Prospect, 4(13), $35-42$.

Putnam R. (1995). Bowling alone: America's declining social capital. Journal of Democracy, 6(1), 65-78. http://dx.doi.org/10.1353/jod.1995.0002

Riaz, F., Bhatti, K. K., \& Shahab-ud-Din. (2014). Macroeconomic Conditions and Firm's Choices of Capital 
Structure: Evidence From Pakistan's Manufacturing Sectors. Middle-East Journal of Scientific Research, 19(4), 521-531.

Taylor, J. B. (1993). Macroeconomic Policy in a World Economy: From Econometric Design to Practical Operation. New York: W. W. Norton.

Taylor, J. B. (1995). The Monetary Transmission Mechanism: An Empirical Framework. Journal of Economic Perspectives, (9), 11-26. http://dx.doi.org/10.1257/jep.9.4.11

Tobin, J. (1969). A General Equilibrium Approach to Monetary Theory. Journal of Money, Credit, and Banking, (1), 15-29. http://dx.doi.org/10.2307/1991374

\section{Copyrights}

Copyright for this article is retained by the author(s), with first publication rights granted to the journal.

This is an open-access article distributed under the terms and conditions of the Creative Commons Attribution license (http://creativecommons.org/licenses/by/3.0/). 